\title{
DERIVATION OF MOTIVATORS FOR THE USE OF ALUMINUM FOAM SANDWICH AND ADVANTAGEOUS APPLICATIONS
}

\author{
Hommel, Patrick; \\ Roth, Daniel; \\ Binz, Hansgeorg \\ University of Stuttgart
}

\begin{abstract}
Aluminum foam sandwich (AFS) is an innovative material combination for designing lighter products and has many advantages such as a high bending stiffness at a low density and good energy absorption properties. Although the material is ready for series production, the number of industrial applications is low because of the high costs of the material, a lack of design knowledge and missing reference applications. This paper focuses on the aspect of missing reference applications and how to improve this situation in order to give designers an idea of where the material could be used profitably and to provide the basis for a selection method. Therefore, a systematic literature review is carried out to identify profitable applications with their respective advantages. As a main result, a set of motivators for the use of aluminum foam sandwich is developed, which will support the designer in evaluating the potential use of aluminum foam sandwich.
\end{abstract}

Keywords: Aluminum foam sandwich, Lightweight design, Design for X (DfX), Decision making

\section{Contact:}

Hommel, Patrick

University of Stuttgart

Institute for Engineering Design and Industrial Design

Germany

patrick.hommel@iktd.uni-stuttgart.de 


\section{INTRODUCTION AND MOTIVATION}

The challenge of making products and structures lighter opens up a wide range of applications for sandwich materials. In particular, aluminum foam sandwich (AFS), which is shown in Figure 1, is an innovative material combination for the use of constructions in lightweight design (Banhart et al., 2017; Binz et al., 2018; Sviridov, 2011). The top layers of AFS are typically made of aluminum alloy sheets, although other materials such as stainless steel may also be used (Baumeister, 1999). The core of the sandwich consists of a porous foam structure made of aluminum. Among the large number of possible manufacturing processes (Banhart, 2018), the powder metallurgical route has become well-established for AFS with aluminum face sheets, because it is well suited for industrial applications (Orovčík et al., 2016). This manufacturing process creates a metallic bond between the face sheets and the foam core, which requires no adhesives and has a high recycling quality (Seeliger, 2011). Due to other advantages, such as a high bending stiffness at a low density and good energy absorption properties, the aluminum foam sandwich has a wide range of possible applications (Banhart et al., 2017; Sviridov, 2011).

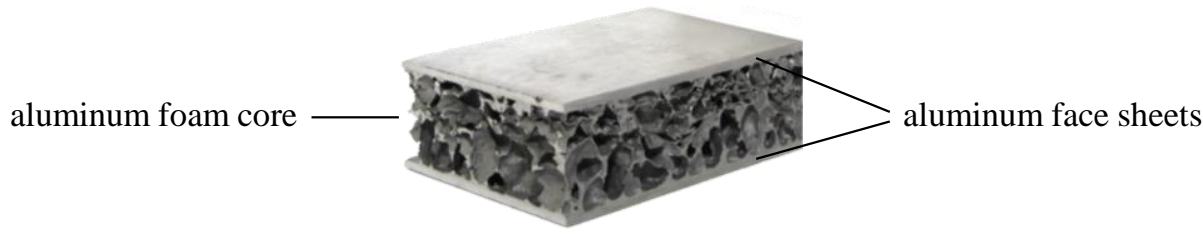

Figure 1. Aluminum foam sandwich

\section{PROBLEM AND GOAL}

Although there are many advantages of aluminum foam sandwich and the material is ready for series production (Seeliger, 2011), the number of industrial applications is below the potential of the material (Banhart et al., 2017). The reasons for the obstacles to the use of AFS were investigated in a survey within the industrial environment (Hommel et al., 2020). The main reasons for the non-use were high costs, a lack of design knowledge and missing reference applications. While the price will decrease with increasing use of the material, the lack of design knowledge as well as the lack of reference applications suggests a need for more research. There are already different approaches to how a design support could be realized in order to make design knowledge available, for example by providing design guidelines.

In this paper the main focus is on the aspect of missing reference applications and how they can be compiled. The current situation indicates that designers do not know where the material can be used profitably. According to Seeliger (2004), an optimal utilization of the material characteristics is very important for a successful AFS application. An application should combine different advantages of the material in order to ensure a significant technical and economic benefit for the user.

In conclusion, a support for the usage of the material is needed, which means that a selection method for identifying the targeted use of AFS has to be developed in the future. Therefore, past applications are relevant as well as an analysis of the respective application criteria. A systematic literature review will help to answer the main questions about where AFS has been used or could be used and which advantages result from this. Thus, the aim of this paper is to provide an overview of the applications and to develop a set of criteria for the application, which is the basis for a future selection method. The research question is: What are the motivators for using aluminum foam sandwich and which applications do they enable?

\section{STRUCTURE OF THIS PAPER}

In the former sections, the research is clarified (RC), which is the first step of the Design Research Methodology (DRM) according to Blessing and Chakrabarti (2009). The DRM provides the methodological framework for this paper. Within the next two sections the detailed first descriptive study (DS I) is conducted. Section 4 shows current and past projects of a large German manufacturer of aluminum foam sandwich to give a brief insight into the state of the art. Moreover, the motivation for the usage of AFS and the advantages compared to materials that have been substituted in these described projects are explained. In Section 5, the motivation for the use of AFS is elaborated with a systematic literature review. The results of the two analyses are then combined in Section 6 as an initial prescriptive 
study (PS). As a result, a support in the form of an overview table with different motivators for use and assigned possible reference applications is worked out. In Section 7 the findings are summarized and critically discussed. The paper concludes with an outlook on further activities.

\section{CURRENT APPLICATIONS IN INDUSTRY - AN INSIGHT INTO THE STATE OF ART}

Before the detailed literature research was conducted, previously known applications from the industry were examined first. To get an impression of the various advantages of the material, exemplary projects of a manufacturer for aluminum foam sandwich were analyzed. Table 1 lists various applications with corresponding reasons for using aluminum foam sandwich instead of another material.

Table 1. Various applications with respective reasons for using aluminum foam sandwich

\begin{tabular}{|l|l|l|}
\hline Applications & Motivators for the usage of AFS & Substituted material \\
\hline Step of a train & Mass reduction to reduce energy costs & Solid aluminum \\
\hline Part of a moving machine table & $\begin{array}{l}\text { Mass reduction for improved acceleration, damping effect } \\
\text { for more even movement }\end{array}$ & Casting \\
\hline $\begin{array}{l}\text { Base plate for manually } \\
\text { exchangeable testing device }\end{array}$ & $\begin{array}{l}\text { Mass reduction in favor of better handling and no lifting } \\
\text { gear (crane) }\end{array}$ & Solid aluminum \\
\hline Partition wall of a compressor unit & Sound insulation and easier installation & Steel sheet \\
\hline $\begin{array}{l}\text { Back wall of a monitor / industrial } \\
\text { touch panel }\end{array}$ & $\begin{array}{l}\text { Mass reduction, better heat dissipation, integration of } \\
\text { functions through electromagnetic shielding and thus } \\
\text { reduction of manufacturing costs }\end{array}$ & Solid aluminum \\
\hline Protective housing of a gear unit & Energy absorption and protection in case of control failure & - \\
\hline $\begin{array}{l}\text { Multiple transport packaging for } \\
\text { explosives }\end{array}$ & $\begin{array}{l}\text { Energy absorption, explosion protection, heat resistance, } \\
\text { cost reduction (previously single packaging of other } \\
\text { materials necessary for safety reasons) }\end{array}$ & $\begin{array}{l}\text { Various } \\
\text { (Single packaging) }\end{array}$ \\
\hline
\end{tabular}

Mass reduction is often cited as a reason to achieve further positive effects. Havel metal foam $\mathrm{GmbH}$ (2019) advertises that in addition to mass reduction, at least one other advantage (e.g. energy absorption, easier processing, fire resistance) should be considered in order to generate new costeffective solutions. This is confirmed by other examples such as bumpers or crash elements in the automotive sector, which enable not only mass reduction but also have high energy absorption and the ability to dampen engine vibrations. The lightweight and protective material may also be used as mobile noise barriers or to separate unattended luggage at the airport (Havel metal foam $\mathrm{GmbH}, 2020$ ).

While this section gave an insight into current applications and prototypes in the industry, the next two sections provide a detailed analysis of the literature of the last decades and collect the applications cited there to provide an overview of the most common motivators for the use of aluminum foam sandwich.

\section{MOTIVATION FOR USING ALUMINUM FOAM SANDWICH - A LITERATURE PERSPECTIVE}

In order to identify the motivators for the use of aluminum foam sandwich from a literature or research perspective, a systematic literature review was planned and conducted. In this section the general procedure is explained and the references found are classified according to their relevance. The following steps were carried out:

1. Definition of the search operations and synonyms for applications of aluminum foam sandwich

2. Execution of the actual research using electronic databases and the previously defined search strategies

3. Review of the sources found and an initial selection

4. Detailed analysis of the selected relevant papers

The results of the analysis of the papers are presented in Section 6.

At the beginning of the literature review the search criteria were defined. The aim was to find different applications of AFS and to identify the respective reasons for its use. As the applications of aluminum foam sandwich and aluminum foam are sometimes not clearly distinguishable in the literature and the applications often resemble each other, both terms were searched for. Then, the found applications have to be verified for their transferability to AFS. When searching for "aluminum foam" also terms with "aluminum foam sandwich" are found at the same time and therefore also terms like "sandwich with 
aluminum foam" were found. So only "aluminum foam" was used as search operation. In addition, the term was searched for both in American English (aluminum) and British English (aluminium). For the central search logic, a combination of terms about material and terms about applications was chosen. Synonyms for the application were for example "use", "usage" or "example". The terms used were examined in an initial search and found to be suitable, while other terms led to a low number of hits. The terms were searched in both, English and German and in singular and plural form.

Four electronic literature databases were used for the search: Science Direct, Web of Science, ProQuest and DOMA Machinery and Plants. The search itself was conducted in October and November 2020.

An unfiltered search with the above-mentioned search logic resulted in a large number of hits (see Figure 2, left), therefore the use of special filters was necessary to reduce the number to an analyzable size. While aluminum foam has been around for several decades (Seeliger, 2011), the development of AFS has been rapid since the mid-1990s and the material has then been brought to technical readiness (Baumeister et al., 1994). Therefore papers published between 1990 and the present (2020) were taken into account. Preferably conference and journal contributions were searched for. If necessary, further filters were set individually for the databases, e.g. topics or categories, to obtain the technical, engineering design and material science context. With these filters set, there were 612 papers remaining. The filtered articles were then screened by analyzing the title, keywords and abstract to see if there are any hints for applications of the material. All papers dealing with different applications of the material were considered potentially relevant, hoping to find more detailed information about the exact reasons and motivations in the main part. Throughout this preselection the number of papers could be further reduced. Papers that were not publicly available were not taken into consideration.

After this procedure there were 228 papers left, which were then examined in more detail and the complete contents were reviewed. Finally, 65 papers could be classified as relevant in terms of applications with assigned reasons. Papers with advantages and reasons for use but without the associated applications mentioned were not considered as relevant for this work. The number of papers was spread over the four databases, with a total of three papers appearing double in two databases (Web of Science and ProQuest). The exact number of papers for the individual steps is shown in Figure 2.

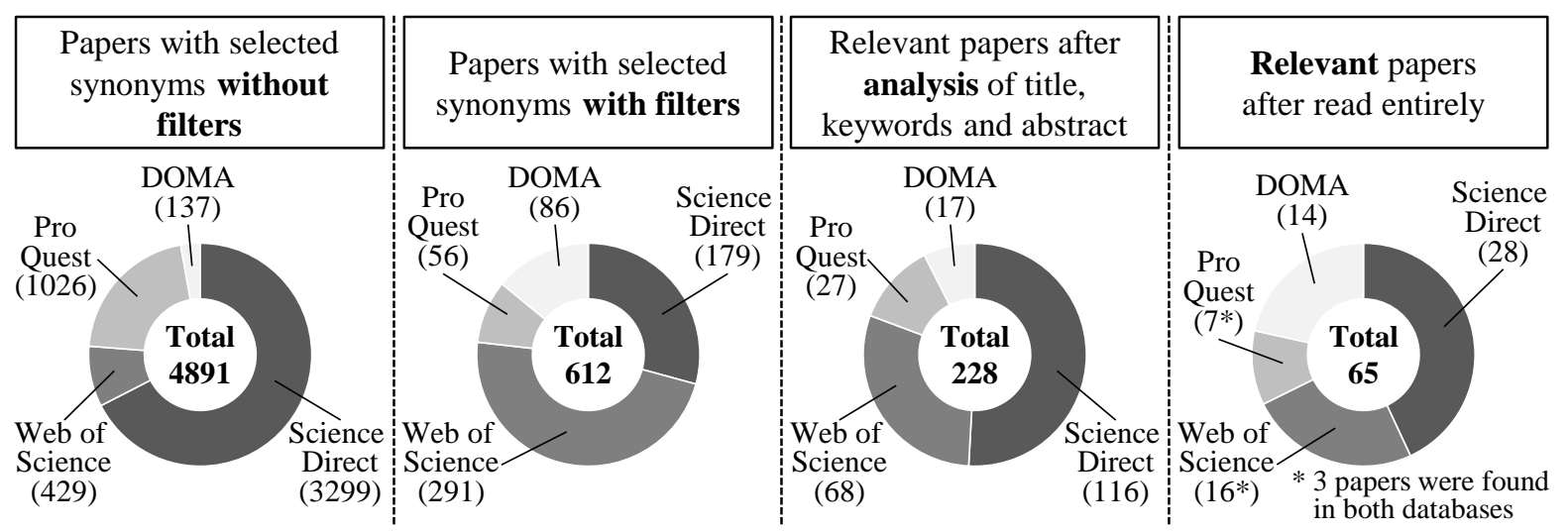

Figure 2. Number of papers related to applications of aluminum foam and aluminum foam sandwich with respective reasons for use

The relevant 65 papers were then analyzed according to their applications and motivation. The results are presented in the next section.

\section{SET OF MOTIVATORS FOR USING ALUMINUM FOAM SANDWICH AND POSSIBLE APPLICATIONS RESULTING FROM IT}

The aim of this section is to list the motivators found for the respective applications and to make a conclusion on the most frequently mentioned aspects. Therefore, the first part will identify the motivators according to the references and in the second part, the corresponding applications are assigned. As explained in Section 5, this paper will only deal with those references that have also related the benefits to a specific application. General statements about the advantages of the material without allocated applications are not considered in this article. A total of 15 different motivators for various applications were identified from the 65 relevant papers. An allocation of the motivators to the references is shown in Table 2. Because three papers were found twice, 62 sources are listed in Table 2. 
Table 2. Set of motivators for using aluminum foam sandwich

Aggogeri et al., 2017

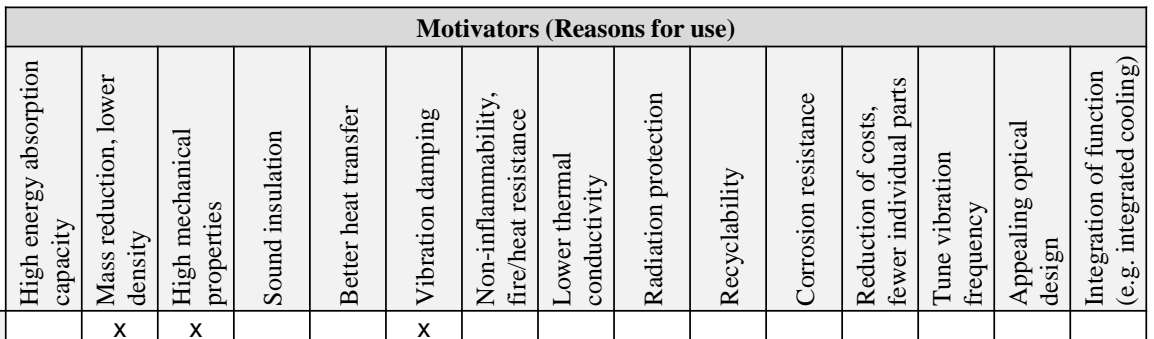

Ahmad and Thambiratnam, 2009

Baiocco et al., 2017

Banhart and Seeliger, 2008

Banhart et al., 1998

Banhart, 1999

Banhart, 2001

Banhart, 2003

Baroutaji et al., 2015

Bauer et al., 2013

Baumeister et al., 1995

Baumeister et al., 2007

Baumeister et al., 2014

Binz et al., 2018

Boomsma et al., 2003

Bornstein and Ackland, 2013

Borosova et al., 2015

Chen et al., 2014

Claar et al., 2000

Crupi et al., 2011

Djamaluddin et al., 2016

Epasto et al., 2020

Fernandez-Morales et al., 2014

Gama et al., 2001

García-Moreno, 2016

Hackert et al., 2017

Hipke et al., 2014

Höfler et al., 2006

Hohlfeld et al., 2015

\& Huisseune et al., 2014

Khateeb et al., 2004

Klan et al., 2007

Knuth, 2015

LaJeunesse, 2015

Lantz et al., 2016

Li et al., 2017a

Li et al., 2017b

Maine and Ashby, 2002

Navacerrada et al., 2013

Noh et al., 2006

Odabaee et al., 2013

Qi et al., 2014

Reglero et al., 2010

Reglero et al., 2011

Rodríguez-Méndez et al., 2019

Rossi et al., 2017

Sampath et al., 2017

Schampheleire et al., 2013

Schmerler et al., 2017

Schultz and Schindler, 2000

Schwingel et al., 2007

Seeliger, 1999

Seeliger, 2004

Setiawan and Salim, 2017

Simon, 2015

Smith et al., 2012

Smith, 2015

Tanaka et al., 2011

Vicario et al., 2016

Wang et al., 2020

Wellnitz, 2011

Zhang et al., 2011

Frequency of mentioned motivators

\begin{tabular}{|c|c|c|c|c|c|c}
\hline $\mathrm{x}$ & & & & & & \\
& & & & $\mathrm{x}$ & & \\
& $\mathrm{x}$ & & & $\mathrm{x}$ & & \\
\hline $\mathrm{x}$ & $\mathrm{x}$ & $\mathrm{x}$ & $\mathrm{x}$ & & $\mathrm{x}$ &
\end{tabular}

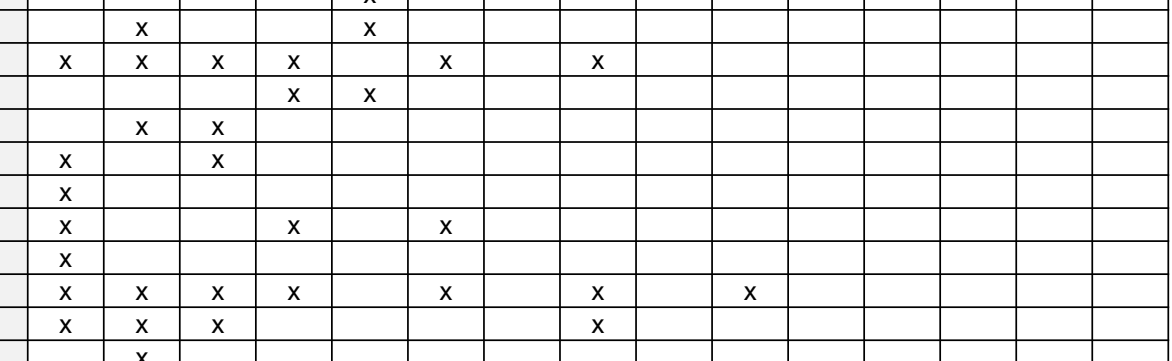

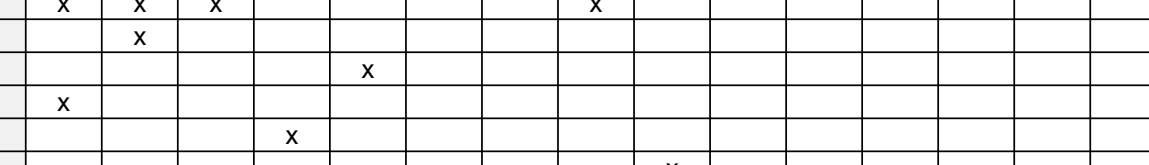

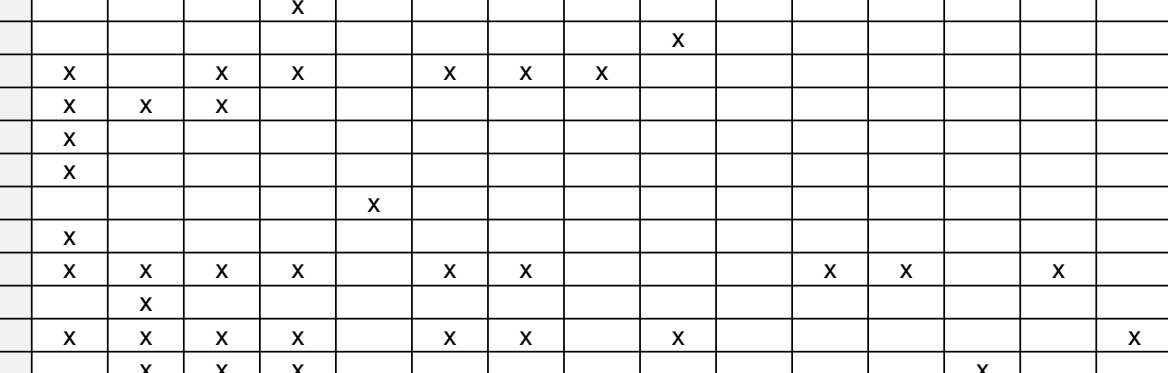

\begin{tabular}{|c|c|c|c|c|c|c|c|c|c|c|}
\hline$x$ & $X$ & $X$ & $\mathrm{X}$ & & $X$ & $X$ & $x$ & & & $\mathrm{X}$ \\
\hline & $x$ & $x$ & $\mathrm{X}$ & & & & & & $x$ & \\
\hline & $x$ & & & & & & & & & \\
\hline & $x$ & & & $x$ & & & & & & \\
\hline & & & & $x$ & & & & & & \\
\hline$x$ & . & $x$ & $\mathrm{X}$ & & & & & & & \\
\hline & $X$ & & $x$ & & $x$ & $x$ & & $X$ & & \\
\hline
\end{tabular}

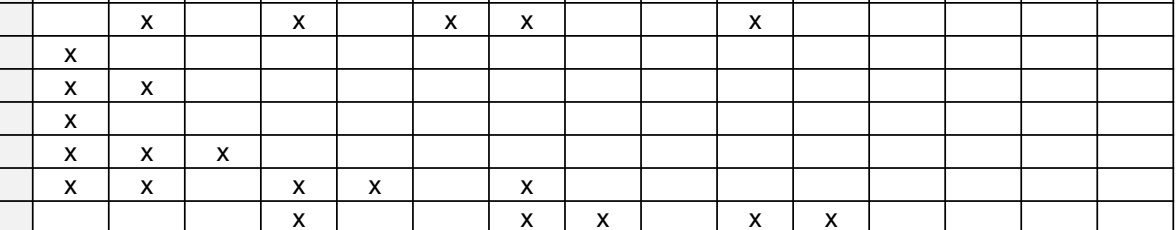

$x$

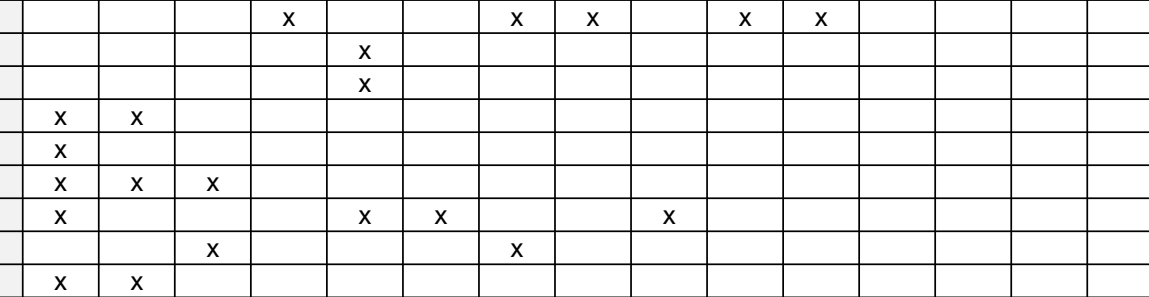

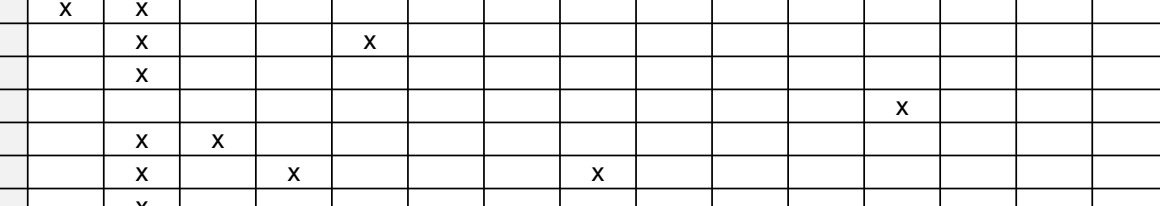

\begin{tabular}{|c|c|c|c|c|c|c|c|c|c|c|c|c|c|c|}
\hline & $\mathrm{X}$ & & & & & & & & & & & & & \\
\hline$x$ & & & & & & & & & & & & & & \\
\hline$X$ & $x$ & & & & & & & & & & & & & \\
\hline$x$ & $x$ & $x$ & & & $x$ & & & & & & & $x$ & & \\
\hline$x$ & & & & & & & & & & & & & & \\
\hline$X$ & $x$ & & & & & & & & & & & & & \\
\hline & $x$ & & & & & & & & & & & & & \\
\hline$x$ & $x$ & $x$ & & & & & & & & & & & & \\
\hline$x$ & $x$ & & & & & & & & & & & & & \\
\hline$x$ & & $x$ & & & & & & & & & & & & \\
\hline 35 & 32 & 19 & 14 & 12 & 10 & 7 & 6 & 3 & 3 & 2 & 2 & 2 & 1 & 1 \\
\hline
\end{tabular}


The frequency of the reasons for using aluminum foam sandwich are summarized in the bottom line of Table 2 and could indicate for which advantages the use of the material is suitable. The most cited motivators are high energy absorption capacity (35 hits), mass reduction/lower density (32 hits), high mechanical properties (19 hits) and the potential for sound insulation (14 hits). The frequent occurrence of high energy absorption capacity ( 35 hits out of 62 references) is remarkable. This trend is also shown by the fact that a lot of references have been published in the last few years. This indicates that the use of AFS for example in crash applications is becoming increasingly important and more future-oriented.

At a first glance the heat specific motivators are notable, since in some applications good heat transfer is cited as the reason for use, while in other applications low thermal conductivity is important. This seems to depend significantly on the application and on the density of the foam. Furthermore, this property must also be seen in relation to a reference material.

With the motivators of Table 2 the advantages, which result from the material usage, were derived consistently. This overview and the following conclusions will help to identify suitable applications in the future. At this point it should also be mentioned that the derived motivator-set does not claim to be complete, as there are certain restrictions to the holistic nature of the literature review. However, due to the systematic approach, a good quantity is reached and the most important aspects are included.

In the second part of the study, the applications with the underlying motivators are presented. Table 3 shows the allocation of applications and motivators and provides information about which applications are mentioned most frequently in the relevant literature (left column) and which applications combine most motivators (right column). For a better understanding, individual applications have been grouped together. For example, crash-relevant vehicle components include a crash box as well as a foam-filled bumper or the B-pillar. Based on the examined references, the allocation was then carried out and the identified motivators were combined as a union for the respective type of application.

\section{Table 3. Applications of aluminum foam sandwich with the respective motivators based on} references

\begin{tabular}{|c|c|c|c|c|c|c|c|c|c|c|c|c|c|c|c|c|c|c|}
\hline & & \multicolumn{15}{|c|}{ Motivators (Reasons for use) } & \multirow[b]{2}{*}{ 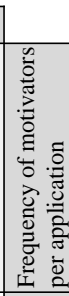 } \\
\hline & & 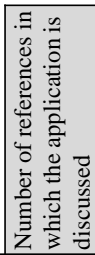 & 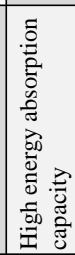 & 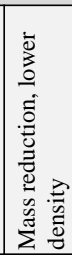 & 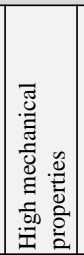 & 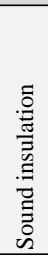 & 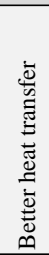 & 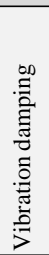 & 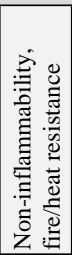 & 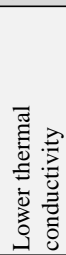 & 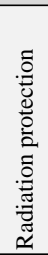 & 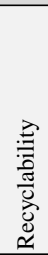 & 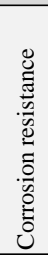 & 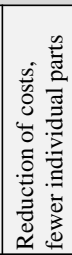 & 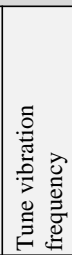 & 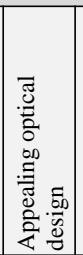 & 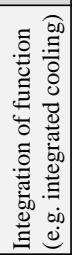 & \\
\hline & \begin{tabular}{|l|}
$\begin{array}{l}\text { Crash-relevant automotive } \\
\text { components, crash absorbers }\end{array}$ \\
\end{tabular} & 19 & $x$ & $x$ & $x$ & $x$ & & $x$ & & & & & & & & & & 5 \\
\hline & $\begin{array}{l}\text { Transportation: train, truck, } \\
\text { ship, metro }\end{array}$ & 17 & $x$ & $x$ & $x$ & $x$ & & $x$ & $x$ & $x$ & & & & $x$ & & & & 8 \\
\hline & Heat exchanger & 10 & & $x$ & & & $x$ & & & & & & & & & & & 2 \\
\hline & \begin{tabular}{|l|}
$\begin{array}{l}\text { Explosion protection, } \\
\text { armouring, military }\end{array}$ \\
\end{tabular} & 9 & $\mathrm{x}$ & $x$ & $x$ & & & & $x$ & & & & & & & & & 4 \\
\hline : & \begin{tabular}{|l|}
$\begin{array}{l}\text { Architecture and building } \\
\text { industry: walls, roofs, floors }\end{array}$ \\
\end{tabular} & 7 & $x$ & $x$ & $x$ & $x$ & & & $x$ & $x$ & $x$ & $x$ & $x$ & & & $x$ & $x$ & 11 \\
\hline . & \begin{tabular}{|l|}
$\begin{array}{l}\text { Components of a machine } \\
\text { tool }\end{array}$ \\
\end{tabular} & 7 & $x$ & $x$ & $x$ & $x$ & & $x$ & & $x$ & & & & & $x$ & & & 7 \\
\hline & \begin{tabular}{|l|} 
Aerospace industry: \\
spacecraft, airplane, rocket
\end{tabular} & 6 & $x$ & $x$ & $x$ & & & $x$ & & & & & & $x$ & $x$ & & & 6 \\
\hline & $\begin{array}{l}\text { Housing for radiation } \\
\text { protection }\end{array}$ & 3 & & & & & & & & & $x$ & & & & & & & 1 \\
\hline & $\begin{array}{l}\text { Battery box of an electric } \\
\text { vehicle }\end{array}$ & 2 & $x$ & $x$ & $\mathrm{x}$ & & & & & $x$ & & & & & & & & 4 \\
\hline & Cookware & 1 & & & & & $x$ & & & & & & & & & & & 1 \\
\hline
\end{tabular}

The frequency with which the applications were mentioned correlates with the importance of the respective application for the use of AFS. Therefore, the greatest potential can be seen in crashrelevant structures in the automotive sector (19 relevant references) as well as in various other transportation vehicles (17 relevant references). Furthermore, applications as heat exchanger and in explosion protection and in the architectural field are often mentioned. Because some literature had several applications, the amount is now greater than the number of references. This distribution of the applications is also intended to fill the gap of missing reference applications shown in previous studies (Hipke and Wunderlich, 2000; Hommel et al., 2020). 
As already discussed in Sections 2 and 4, this investigation has now shown that many applications address several advantages at the same time. Especially in the architecture and building industry (11 motivators) as well as in transportation (8 motivators), a large number of occurring advantages is obvious. The combination of the advantages is necessary to justify the costs of the material and thus to increase the application potential.

\section{CONCLUSION AND OUTLOOK}

The aim of this paper was to develop a set of motivators for the use of AFS and to determine existing applications and the reasons for their use. For this purpose, the authors first analyzed some industrial applications to get a preliminary impression. Then a comprehensive systematic literature review was conducted, which resulted in a large number of applications as well as the corresponding reasons for the use of aluminum foam sandwich. Thereby 15 different motivators for the use of AFS could be identified. The described applications could be allocated to different industries and have various reasons for the use of AFS. Frequently occurring motivators were energy absorption, mass reduction but also mechanical properties as well as absorbing properties. Moreover, it could be determined that the AFS usage in these applications has several advantages at the same time (see Table 2). Thus, this investigation confirmed the assumption that several advantages should be combined when using AFS to justify the price of the material. For mass reasons alone, the use of AFS is rarely profitable. The frequency of the applications mentioned is in accordance with the experience of the authors. It is therefore understandable that especially applications in crash-relevant structures as well as general applications in transport vehicles are promising, which is shown by the large number of references of these applications. Possibly because more costs are allowed here.

However, it must also be noted that there are limitations in the search procedure, e.g. the databases may not find all existing publications. Furthermore, companies often do not publish their applications. Major books such as Ashby et al. (2000) and Hipke et al. (2007) were not selected using the databases, but they already contain the applications shown in the examined papers. Although no claim to completeness can be made, a very large quantity was considered in this investigation and the motivators and applications are valid.

Future investigations will have to extend the set of motivators for the use of aluminum foam sandwich and also evaluate it. In order to support the designer in the material selection and to assist a larger use of aluminum foam sandwich, the reference applications will be visualized and described clearly.

Whereas in this study the applications of AFS have been investigated, a future work may explore the motivators and applications of sandwich panels in general. By comparing the two, it will be possible to check which sandwich areas can currently be served by AFS parts and which cannot. Based on this, the questions of why some areas have not been used so far and whether these could be of interest in the future could be answered and areas where research work is still necessary could also be identified. As described in the introduction, the selection of suitable applications for AFS is a great challenge. Therefore, a selection method has to be developed in order to indicate the parts of an application in which the use of the material is profitable and to support the designer when evaluating the potential of AFS in possible applications using the presented motivator-set.

\section{REFERENCES}

Aggogeri, F., Borboni, A., Merlo, A., Pellegrini, N. and Ricatto, R. (2017), "Vibration Damping Analysis of Lightweight Structures in Machine Tools", Materials, Vol. 10. https://doi.org/10.3390/ma10030297

Ahmad, Z. and Thambiratnam, D.P. (2009), "Dynamic computer simulation and energy absorption of foamfilled conical tubes under axial impact loading", Computers and Structures, Vol 87, pp.186-197.

Ashby, M.F., Evans, A., Fleck, N.A., Gibson, L.J., Hutchinson, J.W. and Wadley, H.N.G. (2000), Metal Foams:

A Design Guide, Butterworth-Heinemann, Woburn, Massachusetts. https://doi.org/10.1016/B978-0-75067219-1.X5000-4

Baiocco, G., Tagliaferri, V. and Ucciardello, N. (2017), "Neural Networks Implementation for Analysis and Control of Heat Exchange Process in a Metal Foam Prototypal Device", 10th CIRP Conference on Intelligent Computation in Manufacturing Engineering (ICME), Ischia, Italy, July 20-22, 2016, pp. 518-522. https://doi.org/10.1016/j.procir.2016.06.035

Banhart, J., Baumeister, J., Melzer, A., Seeliger, W. and Weber, M. (1998), “Aluminiumschaum-

Leichtbaustrukturen für den Fahrzeugbau”, Werkstoffe im Automobilbau - Sonderausgabe ATZ, MTZ. 
Banhart, J. (1999), “Offenporige Aluminiumschäume - Eigenschaften und Anwendungen (Properties and applications of open-pored metallic materials)", Aluminium, Vol. 75.

Banhart, J. (2001), "Manufacture, characterisation and application of cellular metals and metal foams", Progress in Materials Science, Vol. 46, pp. 559-632. https://doi.org/10.1016/S0079-6425(00)00002-5

Banhart, J. (2003), “Aluminum Foams: On the Road to Real Applications”, MRS Bulletin, Vol. 28, pp. $290-295$. https://doi.org/10.1557/mrs2003.83

Banhart, J. and Seeliger, H.-W. (2008), “Aluminium Foam Sandwich Panels: Manufacture, Metallurgy and Applications”, Advanced Engineering Materials, Vol. 10. https://doi.org/10.1002/adem.200800091

Banhart, J., García-Moreno, F., Heim, K. and Seeliger, H.-W. (2017), "Light-weighting in transportation and defence using aluminium foam sandwich structures", International Symposium on Light Weighting for Defence, Aerospace and Transportation, Indian Institute of Metals, Goa, November 11, 2017.

Banhart, J. (2018), "Production of Metal Foams", In: Beaumont, W.R. and Zweben, C.H. (Eds.), Comprehensive Composite Materials II, Vol. 4, pp. 347-363. https://doi.org/10.1016/B978-0-12-803581-8.09976-8

Baroutaji, A., Gilchrist, M.D., Smyth, D. and Olabi, A.G. (2015), “Analysis and optimization of sandwich tubes energy absorbers under lateral loading”, International Journal of Impact Engineering, Vol. 82, pp. 74-88. http://dx.doi.org/10.1016/j.ijimpeng.2015.01.005

Bauer, B., Kralj, S. and Bušić, M. (2013), "Production and Application of Metal Foams in Casting Technology", Tehnički Vjesnik, Vol. 20, pp. 1095-1102.

Baumeister, J., Banhart, J. and Weber, M. (1994), Verfahren zur Herstellung eines metallischen Verbundwerkstoffs (Process for manufacturing metallic composite materials). German Patent DE 4426627.

Baumeister, J., Banhart, H. and Weber, M. (1995), "Hocheffiziente Energieabsorber aus Aluminiumschaum (Highly efficient energy absorbers made of aluminium foam)", VDI Berichte, No. 1235.

Baumeister, J. (1999), "Production technology for aluminium foam/steel sandwiches", In: Banhart, J., Ashby, M.F., Fleck, N.A. (Eds.), Metal Foams and Porous Metal Structures. Bremen: MIT Verlag, pp. 113-118.

Baumeister, J., Rausch, G., Stöbener, K., Lehmhus, D. and Busse, M. (2007), "Verbundwerkstoffe mit Aluminiumschaum - Anwendungen im Schienenfahrzeugbau", Materialwissenschaft und Werkstofftechnik, Vol. 38, No. 11, pp. 939-942. https://doi.org/10.1002/mawe.200700180

Baumeister, J., Weise, J., Hirtz, E., Höhne, K. and Hohe, J. (2014), “Applications of aluminum hybrid foam sandwiches in battery housings for electric vehicles", 8th International Conference on Porous Metals and Metallic Foams, Raleigh, North Carolina, pp. 317-321. https://doi.org/10.1016/j.mspro.2014.07.565

Binz, H., Honold, C., Laufer, F., Hommel, P., Roth, D., Bauernhansl, T. and Schuster, M. (2018), "Konstruktion und Herstellung eines Auslegers aus Aluminiumschaum-Sandwich unter Anwendung der Fräskanttechnik", Konstruktion, No. 07-08/2018, pp. 78-82.

Blessing, L.T.M. and Chakrabarti, A. (2009), DRM, a Design Research Methodology, Springer, London. https://doi.org/10.1007/978-1-84882-587-1

Bornstein, H. and Ackland, K. (2013), "Evaluation of energy absorbing materials under blast loading", Transactions on Engineering Sciences, Vol. 77, pp. 125-136. https://doi.org/10.2495/MC130111

Borosova, L., Liptai, P., Moravec, M., Fedak, G., Konkoly, T. and Lukacova, K. (2015), "The analysis of choosen acoustic descriptors of sandwich absorbers on the aluminum foam base", International Journal of Engineering, pp. 189-194.

Boomsma, K., Poulikakos, D. and Zwick, F. (2003), "Metal foams as compact high performance heat exchangers", Mechanics of Materials, Vol. 35, pp. 1161-1176. https://doi.org/10.1016/j.mechmat.2003.02.001

Chen, S., Bourham, M. and Rabiei, A. (2014), “Applications of open-cell and closed-cell metal foams for radiation shielding”, 8th International Conference on Porous Metals and Metallic Foams, Raleigh, North Carolina, pp. 293-298. https://doi.org/10.1016/j.mspro.2014.07.560

Claar, T.D., Yu, C.-J., Hall, I., Banhart, J., Baumeister, J. and Seeliger, W. (2000), “Ultra-lightweight Aluminum Foam Materials for Automotive Applications”, SAE 2000 World Congress, Detroit, March 6-9, 2000.

Crupi, V., Epasto, G. and Guglielmino, E. (2011), "Impact Response of Aluminum Foam Sandwiches for LightWeight Ship Structures", Metals, Vol. 1, pp. 98-112. https://doi.org/10.3390/met1010098

Djamaluddin, F., Abdullah, S., Ariffin, A.K. and Nopiah, Z.M. (2016), "Finite Element Analysis and Crashworthiness Optimization of Foam-filled Double Circular under Oblique Loading”, Latin American Journal of Solids and Structures, Vol.13, No. 11, pp. 98-112. http://dx.doi.org/10.1590/1679-78252844

Epasto, G., Distefano, F., Gu, L., Mozafari, H. and Linul, E. (2020), "Design and optimization of Metallic Foam Shell protective device against flying ballast impact damage in railway axles", Materials and Design, Vol.196. https://doi.org/10.1016/j.matdes.2020.109120

Fernandez-Morales, P., Nieto, C., Patiño, C., Lopez, J.P., Tamayo, D., Mendoza, E. and Giraldo, M. (2014), “A conceptual design of energy exchange system for recovery of residual heat using aluminum foams", 8th International Conference on Porous Metals and Metallic Foams, Raleigh, North Carolina, pp. 371-376.

Gama, B.A., Bogetti, T.A., Fink, B.K., Yu, C.-J., Claar, T.D., Eifert, H.H. and Gillespie Jr. J.W. (2001), "Aluminum foam integral armor: a new dimension in armor design", Composite Structures, Vol. 52, pp. 381-395. https://doi.org/10.1016/S0263-8223(01)00029-0 
García-Moreno, F. (2016), “Commercial Applications of Metal Foams: Their Properties and Production”, Materials, Vol. 9, No. 85. https://doi.org/10.3390/ma9020085

Hackert, A., Müller, S. and Kroll, L. (2017), "Leichtbau-Radscheibe aus Carbon-Aluschaum-Sandwich", Lightweight Design, No. 10, pp. 10-14. https://doi.org/10.1007/s35725-016-0076-y

Havel metal foam GmbH (2019), Batteriegehäuse der Zukunft aus Aluminiumschaum für die Automobilindustrie. [online]. Available at: https://havel$\mathrm{mf} . \mathrm{com} / \mathrm{unternehmen/downloads?file=files/bilder/3 \% 20Unternehmen/6 \% 20Downloads/D \_ 20190815}$ HMF_Batterie-Geha\%CC\%88use.pdf (accessed 12.11.2020).

Havel metal foam GmbH (2020), Industry solutions. [online]. Available at: https://en.havel$\mathrm{mf} . c o m /$ Industrysolutions (accessed 23.11.2020).

Hipke, T. and Wunderlich, T. (2000), "Chancen und Hemmnisse für den Metallschaumeinsatz", Materialwissenschaft und Werkstofftechnik, Vol. 31, No. 6, pp. 396-399. https://doi.org/10.1002/15214052(200006)31:6\&lt;396::AID-MAWE396>3.0.CO;2-4

Hipke, T., Lange, G. and Poss, R. (2007), Taschenbuch für Aluminiumschäume, Aluminium-Verlag, Düsseldorf.

Hipke, T., Hohlfeld, J. and Rybandt, S. (2014), "Functionally aluminum foam composites for building industry", 8th International Conference on Porous Metals and Metallic Foams, Raleigh, North Carolina, pp. 133-138. https://doi.org/10.1016/j.mspro.2014.07.550

Höfler, D., Priebsch, H.H., Rust, A. and Brandl, F.K. (2006), "Geräuschreduktion von Motorbauteilen durch hoch dämpfende Werkstoffe”, Motortechnische Zeitschrift (MTZ), No. 67, pp. 860-868. https://doi.org/10.1007/BF03225426

Hohlfeld, J., Ketzscher, R., Drebenstedt, C. and Lies, C. (2015), Entwicklung einer Triebkopfkabine aus Aluminiumschaum-Halbzeugen für Hochgeschwindigkeitszüge.

Hommel, P., Roth, D. and Binz, H. (2020), "Deficits in the application of aluminum foam sandwich: An industrial perspective", 16th International Design Conference, October 26-29, 2020, Cambridge University Press, pp. 927-936. https://doi.org/10.1017/dsd.2020.13

Huisseune, H., Jaeger, P., Schlampheleire, S., Ameel, D. and Paepe, M. (2014), “ Simulation of an aluminum foam heat exchanger using the volume averaging technique", 8th International Conference on Porous Metals and Metallic Foams, Raleigh, North Carolina, pp. 353-358. https://doi.org/10.1016/j.mspro.2014.07.572

Khateeb, S.A., Farid, M.M., Selman, J.R. and Al-Hallaj, S. (2004), "Design and simulation of a lithium-ion battery with a phase change material thermal management system for an electric scooter", Journal of Power Sources, Vol. 128, pp. 292-307. https://doi.org/10.1016/j.jpowsour.2003.09.070

Klan, S., Kniewallner, L., Philipp, S. and Weid, D. (2007), “Aluminiumschaum zur Verbesserung der Akustik und des Crashverhaltens”, Motortechnische Zeitschrift (MTZ), No. 68, pp. 960-964. https://doi.org/10.1007/BF03227445

Knuth, L. (2015), "Recyclingfähiges Material für den Leichtbau”, Lightweight Design, No. 8, pp. 20-25. https://doi.org/10.1007/s35725-015-0013-5

LaJeunesse, J. (2015), Implications of heterogeneity in the shock wave propagation of dynamically shocked materials, Master's Thesis, Marquette University, Milwaukee, Wisconsin.

Lantz, L., Maynez, J., Cook, W. and Wilson, C.M.D. (2016), "Blast Protection of Unreinforced Masonry Walls: A State-of-the-Art Review”, Advances in Civil Engineering, Vol. 2016. http://dx.doi.org/10.1155/2016/8958429

Li, Z., Yu, Q., Zhao, X., Yu, M., Shi, P. and Yan, C. (2017a), "Crashworthiness and lightweight optimization to applied multiple materials and foam-filled front end structure of auto-body", Advances in Mechanical Engineering, Vol. 9, pp. 1-21. https://doi.org/10.1177/1687814017702806

Li, Z., Jiang, B. and Lu, F. (2017b), "Dynamic crushing of cellular materials with temperature gradient", 11th International Symposium on Plasticity and Impact Mechanics (Implast), December 11 - 14, 2016, New Delhi, India, pp. 1992-1999. https://doi.org/10.1016/j.proeng.2017.05.145

Maine, E.M.A. and Ashby, M.F. (2002), "Applying the investment methodology for materials (IMM) to aluminium foams", Materials and Design, Vol. 23, pp. 307-319.

Navacerrada, M.A., Fernández, P., Díaz, C. and Pedrero, A. (2013), "Thermal and acoustic properties of aluminium foams manufactured by the infiltration process", Applied Acoustics, Vol. 74, pp. 496-501. http://dx.doi.org/10.1016/j.apacoust.2012.10.006

Noh, J.S., Lee, K.B. and Lee, C.G. (2006), "Pressure loss and forced convective heat transfer in an annulus filled with aluminum foam”, International Communications in Heat and Mass Transfer, Vol. 33, pp. 434-444. https://doi.org/10.1016/j.icheatmasstransfer.2005.11.003

Odabaee, M., Mancin, S. and Hooman, K. (2013), "Metal foam heat exchangers for thermal management of fuel cell systems - An experimental study”, Experimental Thermal and Fluid Science, pp. 214-219. http://dx.doi.org/10.1016/j.expthermflusci.2013.07.016

Orovčík, L., Nosko, M., Kováčik, J., Dvorák, T., Štěpánek, M. and Simančík, F. (2016), "Effects of chemical composition on the pore structure and heat treatment on the deformation of PM aluminium foams 6061 and 7075”, Metallic Materials, Vol. 54, No. 6, pp. 463-470. https://doi.org/10.4149/km_2016_6_463 
Qi, C., Yang, S., Yang, L.-J., Han, S.-H. and Lu, Z.-H. (2014), "Dynamic Response and Optimal Design of Curved Metallic Sandwich Panels under Blast Loading”, The Scientific World Journal, Vol. 2014.

Reglero, J.A., Solórzano, E., Rodríguez-Pérez, M.A., de Saja, J.A. and Porras, E. (2010), "Design and testing of an energy absorber prototype based on aluminium foams", Materials and Design, Vol. 31, pp. 3568-3573. https://doi.org/10.1016/j.matdes.2010.02.025

Reglero, J.A., Rodríguez-Pérez, M.A., Solórzano, E., and de Saja, J.A. (2011), “Aluminium foams as a filler for leading edges: Improvements in the mechanical behaviour under bird strike impact tests", Materials and Design, Vol. 32, pp. 907-910. https://doi.org/10.1016/j.matdes.2010.08.035

Rodríguez-Méndez, F., Meneses-Guzmán, M. and Chinè-Polito, B. (2019), "Behavior of an aluminum foam as an attenuator of electromagnetic radiation", Tecnologia en Marcha, Vol. 32, pp. 7-17. https://doi.org/10.18845/tm.v32i5.4166

Rossi, S., Bergamo, L. and Fontanari, V. (2017), "Fire resistance and mechanical properties of enamelled aluminium foam”, Materials and Design, Vol. 132, pp. 129-137. https://doi.org/10.1016/j.matdes.2017.06.064

Sampath, V., Rao, C.L. and Reddy, S. (2017), "Energy Absorption of Foam Filled Aluminum Tubes under Dynamic Bending", International Conference on Sustainable Materials Processing and Manufacturing (SMPM), January 23-25, 2017, Kruger National Park, South Africa, pp. 225-233. https://doi.org/10.1016/j.promfg.2016.12.054

Schampheleire, S., Jaeger, P., Huisseune, H., Ameel, B., T’Joen, C., Kerpel, K. and Paepe, M. (2013), “Thermal hydraulic performance of 10 PPI aluminium foam as alternative for louvered fins in an HVAC heat exchanger", Applied Thermal Engineering, Vol. 51, pp. 371-382. http://dx.doi.org/10.1016/j.applthermaleng.2012.09.027

Schmerler, R., Gebken, T., Kalka, S. and Reincke, T. (2017), "Funktionsintegriertes Batteriegehäuse für Elektrofahrzeuge”, Lightweight Design, No. 5/2017, pp. 32-37. https://doi.org/10.1007/s35725-017-0047-y

Schultz, O. and Schindler, R. (2000), “Aluminiumschaum: Dynamische Festigkeit und Anwendung im Hubschrauber", Materialwissenschaft und Werkstofftechnik, Vol. 31, pp. 511-514.

Schwingel, D., Seeliger, H.-W., Vecchionacci, C., Alwes, D. and Dittrich, J. (2007), "Aluminium foam sandwich structures for space applications", Acta Astronautica, Vol. 61, pp. 326-330. https://doi.org/10.1016/j.actaastro.2007.01.022

Seeliger, H.-W. (1999), “Application Strategies for Aluminum-Foam-Sandwich Parts (AFS)”, In: Banhart, J., Ashby, M.F., Fleck, N.A. (Eds.), Metal Foams and Porous Metal Structures, pp. 29-36.

Seeliger, H.-W. (2004), “Aluminium Foam Sandwich (AFS) Ready for Market Introduction”, Advanced Engineering Materials, Vol. 6, No. 6, pp. 448-451. https://doi.org/10.1002/adem.200405140

Seeliger, H.-W. (2011), “AFS-Weiterentwicklung erreicht Serienreife: Aluminiumschaum frisch vom Band”, Aluminium Kurier News, No. 03/2011, p. 16.

Setiawan, R., and Salim, M.R. (2017), "Crashworthiness Design for an Electric City Car against Side Pole Impact”, Journal of Engineering and Technological Sciences, Vol. 49, pp. 587-603. http://dx.doi.org/10.5614\%2Fj.eng.technol.sci.2017.49.5.3

Simon, M. (2015), "Experimental research regarding rigidity improvement of hollow machine tools structures using aluminum foam", 8th International Conference Interdisciplinarity in Engineering (INTER-ENG), October 9-10, 2014, Tirgu-Mures, Romania, pp. 228-232. https://doi.org/10.1016/j.protcy.2015.02.033

Smith, B.H., Szyniszewski, S., Hajjar, J.F., Schafer, B.W. and Arwade, S.R. (2012), "Steel foam for structures: A review of applications, manufacturing and material properties", Journal of Constructional Steel Research, Vol. 71, pp.1-10. https://doi.org/10.1016/j.jcsr.2011.10.028

Smith, R.M. (2015), Experimental Testing of Aluminum Foam Filled Stainless Steel Braided Tubes Subjected to Transverse Impact, Master's Thesis, University of Windsor, Ontario, Canada.

Sviridov, A. (2011), Leichtbau mit Aluminiumschaumsandwich: Prozessketten zur Herstellung von Bauteilen, $\mathrm{PhD}$ Thesis, Brandenburg University of Technology Cottbus.

Tanaka, S., Hokamoto, K., Irie, S., Okano, T., Ren, Z., Vesenjak, M. and Itoh, S. (2011), "High-velocity impact experiment of aluminum foam sample using powder gun”, Measurement, Vol. 44, pp. 2185-2189. https://doi.org/10.1016/j.measurement.2011.07.018

Vicaria, I., Crespo, I., Plaza, L.M., Caballero, P. and Idoiaga, I.K. (2016), “Aluminium Foam and Magnesium Compound Casting Produced by High-Pressure Die Casting”, Metals, Vol. 6. https://doi.org/10.3390/met6010024

Wang, X., He, W. and Zhao, L. (2020), "Interval Identification of Thermal Parameters Using Trigonometric Series Surrogate Model and Unbiased Estimation Method”, Applied Sciences, Vol. 10. https://doi.org/10.3390/app10041429

Wellnitz, J. (2011), “Aluminiumschaum für hohe Dauerfestigkeit und Ermüdungsbelastung”, Lightweight Design, No. 4, pp. 28-31. https://doi.org/10.1365/s35725-011-0017-8

Zhang, X., Jia, G. and Huang, H. (2011), "Numerical Investigation of Aluminum Foam Shield Based on Fractal Theory and Node-separation FEM", Chinese Journal of Aeronautics, Vol. 24, pp. 734-740.

https://doi.org/10.1016/S1000-9361(11)60086-1 